\title{
Role of thyroid hormones in early postnatal development of skeletal muscle and its implications for undernutrition
}

\author{
BY A. P. HARRISON ${ }^{1}$, D. R. TIVEY ${ }^{1}$, T. CLAUSEN², C. DUCHAMP ${ }^{1}$ AND \\ M. J. DAU NCEY ${ }^{1 *}$ \\ ${ }^{1}$ Department of Cellular Physiology, The Babraham Institute, Cambridge CB2 4AT \\ ${ }^{2}$ Department of Physiology, University of Aarhus, DK-8000 Århus C, Denmark
}

(Received 7 December 1995 -Revised 22 April 1996 - Accepted 1 May 1996)

\begin{abstract}
Energy intake profoundly influences many endocrine axes which in turn play a central role in development. The specific influence of a short period of mild hypothyroidism, similar to that induced by undernutrition, in regulating muscle development has been assessed in a large mammal during early postnatal life. Hypothyroidism was induced by providing methimazole and iopanoic acid in the feed of piglets between 4 and $14 \mathrm{~d}$ of age, and controls were pair-fed to the energy intake of their hypothyroid littermates. Thyroid status was evaluated, and myofibre differentiation and cation pump concentrations were then assessed in the following functionally distinct muscles: longissimus dorsi (l. dorsi), soleus and rhomboideus. Reductions in plasma concentrations of thyroxine $\left(\mathrm{T}_{4} ; 32 \%, P<0.01\right)$, triiodothyronine $\left(\mathrm{T}_{3} ; 48 \%, P<0.001\right)$, free $\mathrm{T}_{3}(58 \%, P<0.001)$ and hepatic 5 -monodeiodinase $(E C 1.11 .1 .8)$ activity $(74 \%, P<0.001)$ occurred with treatment. Small, although significant, increases in the proportion of type I slow-twitch oxidative fibres occurred with mild hypothyroidism, in $l$. dorsi $(2 \%, P<0.01)$ and soleus $(7 \%, P<0.01)$. Nuclear $\mathrm{T}_{3}$-receptor concentration in $l$. dorsi of hypothyroid animals compared with controls increased by $46 \%(P<0.001)$, a response that may represent a homeostatic mechanism making muscle more sensitive to low levels of circulating thyroid hormones. Nevertheless, $\mathrm{Na}^{+}, \mathrm{K}^{+}-$ ATPase (EC 3.6.1.37) concentration was reduced by $15-16 \%$ in all muscles $(l$. dorsi $P<0.05$, soleus $P<0.001$, rhomboideus $P<0.05)$, and $\mathrm{Ca}^{2+}$-ATPase $(E C$ 3.6.1.38) concentration was significantly reduced in the two slow-twitch muscles: by $22 \%$ in rhomboideus $(P<0.001)$ and $23 \%$ in soleus $(P<0.05)$. It is concluded that during early postnatal development of large mammals a period of mild hypothyroidism, comparable with that found during undernutrition, induces changes in myofibre differentiation and a down-regulation of cation pumps in skeletal muscle. Such changes would result in slowness of movement and muscle weakness, and also reduce ATP hydrolysis with a concomitant improvement in energetic efficiency.
\end{abstract}

$\mathrm{Ca}^{2+}$-ATPase: Muscle: $\mathrm{Na}^{+}, \mathrm{K}^{+}$-ATPase: Thyroid: Undernutrition

Normal muscle development is essential for many functions including maintenance of posture, movement and thermogenesis. The acquisition of contractile ability is achieved in part by both the differentiation of muscle fibres and the maturation of two cation pumps: the sarcolemmal (SL) $\mathrm{Na}^{+}, \mathrm{K}^{+}$-ATPase (EC 3.6.1.37) and the sarcoplasmic reticulum (SR) $\mathrm{Ca}^{2+}$-ATPase (EC 3.6.1.38) (Clausen et al. 1991). Both these ATPases undergo marked developmental up-regulation in porcine muscle during the first 2 weeks postnatally (Dauncey et al. 1994; Harrison et al. 1994a), indicating that this period of life may be particularly susceptible to modifications by environmental factors such as nutrition, ambient temperature, activity, or hormonal status which could in turn impair the normal development of muscle.

Both the quantity and composition of food eaten influence thyroid hormone (TH) status

* For reprints. 
(Dauncey, 1990) which in turn plays a major role in regulating myofibre differentiation (d'Albis \& Butler-Browne, 1993; Dauncey \& Gilmour, 1996) and cation pump concentrations (Clausen et al. 1991). In adult rats severe hypothyroidism over prolonged periods results in conversion of fast- to slow-twitch fibres (McAllister et al. 1991) and reduced rates of muscle contraction and relaxation (Gold et al. 1970), which explains in part the associated slowness of movement and muscle weakness. Moreover, muscle function would also be affected by the down-regulation of $\mathrm{Na}^{+}-\mathrm{K}^{+}$- and $\mathrm{Ca}^{2+}$-ATPase concentrations which occurs in severe hypothyroidism (Kjeldsen et al. 1986a; Simonides \& van Hardeveld, 1989).

Much less well understood is the extent to which the mild hypothyroidism associated with undernutrition (Dauncey, 1990) affects muscle development and whether changes can be exerted within a short period of time, especially in young growing animals. The aim of the present study, therefore, was to determine the effect of a short period of pharmacologically-induced mild hypothyroidism, comparable with that due to a $50 \%$ reduction in energy intake, on myofibre proportions and cation pump concentrations in three morphologically and functionally distinct skeletal muscles during the first 2 weeks of postnatal development in a large mammalian species. To avoid any influence of changes in feed intake with induced hypothyroidism, care was taken to ensure that controls were pairfed to the feed intake of hypothyroid animals. Furthermore, animals were kept at thermal neutrality to ensure that environmentally-induced changes in energy expenditure were avoided. Part of this work has been the subject of preliminary communications (Harrison et al. 1993, 1994c).

\section{METHODS}

\section{Subjects and experimental design}

Piglets ( $n$ 18) of the Large White breed were left with the sow until $2 \mathrm{~d}$ of age to enable the feeding of colostrum. Animals within the same litter were paired for similar birth weight, of approximately $1.4 \mathrm{~kg}$. Piglets were housed in pairs in temperature-controlled rooms at thermal neutrality, which is approximately $34^{\circ}$ at $2 \mathrm{~d}$ of age. The temperature was reduced by $1^{\circ}$ every $3 \mathrm{~d}$ to allow for the known decrease in critical temperature with age (Mount, 1979). Each pair of animals was bottle-fed to repletion four times daily (at 12.00, 18.00, $00.00,06.00$ hours) for the first 2-4 d with sow's milk-replacement formula (Lifeline; British Denkavit, Poole, Dorset). This formula is available as a complete milk replacer for piglets and as such it can be used to rear piglets in the absence of the sow. Lifeline contains (g/kg): sugar (as lactose) 482, protein 173, fat 159, ash 101, moisture 26, starch 2, and added vitamins, and provides $17 \cdot 8 \mathrm{~kJ} / \mathrm{g}$. It is reconstituted with water at a concentration of $150 \mathrm{~g}$ powder $/ 1$ mixed milk.

At the start of day 4 (12.00 hours) animals were weighed and within each pair were assigned randomly to either the control or hypothyroid group. Mild hypothyroidism was induced by providing the following compounds in the feed: methimazole, which blocks thyroidal production of TH, and iopanoic acid, which blocks peripheral conversion of $\mathrm{T}_{4}$ to $T_{3}$. Initial starter doses of $30 \mathrm{mg}$ methimazole $/ \mathrm{kg}$ and $4 \cdot 1 \mathrm{mg}$ iopanoic acid $/ \mathrm{kg}$ were provided. At subsequent six-hourly feeds hypothyroid piglets were given $7.5 \mathrm{mg}$ methimazole $/ \mathrm{kg}$ and $1.0 \mathrm{mg}$ iopanoic acid $/ \mathrm{kg}$. The daily dose of methimazole was estimated on the basis of previous studies in the young pig (Morovat \& Dauncey, 1995) and that for iopanoic acid was based on the amount used for human subjects (Acheson \& Burger, 1980). This treatment induced mild hypothyroidism (see p. 846) but otherwise the animals were in good health and had a good appetite at each meal. Control piglets were pair-fed to the feed intake of their hypothyroid littermates on the basis of metabolic body size $\left(\mathrm{g} / \mathrm{kg}^{0.67}\right)$. Animals were maintained on this treatment until aged $14 \mathrm{~d}$. 


\section{Plasma and tissue samples}

After $3 \mathrm{~d}$ of treatment, at the age of $7 \mathrm{~d}, 0.5 \mathrm{ml}$ blood from the vein corresponding to the median vein of the elbow in human subjects was obtained from both control and hypothyroid animals, for measurement of plasma TH concentrations. After $10 \mathrm{~d}$ of treatment piglets were sedated at least $9 \mathrm{~h}$ after their last meal by an intramuscular injection of ketamine hydrochloride $(0.5 \mathrm{ml}$ Vetalar $(100 \mathrm{mg} / \mathrm{ml})$; Parke-Davis Veterinary, Pontypool, Gwent). Blood samples $(5 \mathrm{ml})$ were then taken by cardiac puncture into heparinized tubes and plasma was stored at $-40^{\circ}$. Animals were killed by injection of $0.7 \mathrm{ml}$ pentobarbitone sodium (Lethobarb, $200 \mathrm{~g} / 1$; Duphar Veterinary Ltd, Southampton, Hants) $/ \mathrm{kg}$. All procedures were carried out with full authorization from the UK Home Office. The liver and three functionally and morphologically distinct skeletal muscles were dissected and small pieces were frozen rapidly and stored at $-40^{\circ}$. Tissue samples for histochemistry were frozen in 2-methylbutane (isopentane) cooled by liquid $\mathrm{N}_{2}$ while all other tissue samples were frozen directly in liquid $\mathrm{N}_{2}$. The muscles investigated were $l$. dorsi, a predominantly type II fast-twitch muscle of the thoracic-lumbar region, used for rapid movement; soleus, with a high proportion of type I slow-twitch fibres, associated with maintenance of posture; and rhomboideus, also a postural muscle but of interscapular origin with a postulated key role in thermoregulation.

\section{Plasma thyroid hormone concentrations}

Total 3,5,3',5'-tetraiodo-L-thyronine (thyroxine; $\mathrm{T}_{4}$ ) and total 3,5,3'-triiodothyronine $\left(\mathrm{T}_{3}\right)$ concentrations were measured using commercially available kits (Coat-a-Count; Diagnostic Products Corporation, Los Angeles, CA, USA), which incorporate a solid-phase radioimmunoassay (RIA) system. Free $\mathrm{T}_{3}$ was measured using a Liso-phase Sclavo kit (Metachem Diagnostics Ltd, Northampton). The method incorporated separation of free $\mathrm{T}_{3}$ by chromatography and RIA of the adsorbed hormone using solid-phase separation of the bound antibody from the free antigen.

\section{Hepatic 5'-monodeiodinase (EC 1.11.1.8) activity}

Hepatic $5^{\prime}$-monodeiodinase activity was assessed because peripheral conversion of $T_{4}$ to $T_{3}$ represents a major source of circulating $T_{3}$ in the young pig (Slebodziński et al. 1985). The method of Kühn et al. (1987) was used, with some modification. Liver (approximately $4 \mathrm{~g}$ ) was homogenized in 4 vol. phosphate buffer $(150 \mathrm{mmol} / 1), \mathrm{pH} 7 \cdot 4$, and spun at $700 \mathrm{~g}$ for $10 \mathrm{~min}$. Portions $(100 \mu \mathrm{l})$ of the microsomal fraction (approximately $2 \mathrm{mg}$ protein) were incubated for $30 \mathrm{~min}$ at $37^{\circ}$ with $100 \mu \mathrm{l} \mathrm{T} \mathrm{T}_{4}(1.0 \mu \mathrm{mol} / \mathrm{l})$ in the presence of $100 \mu \mathrm{l}$ dithiothreitol $(7.5 \mathrm{mmol} / \mathrm{l})$. The reaction was stopped by cooling the tubes on ice and addition of $1 \mathrm{ml}$ ethanol $(950 \mathrm{ml} / \mathrm{l})$. Blank tubes contained no $\mathrm{T}_{4}$ during the incubation but had $\mathbf{T}_{4}$ added after the addition of ethanol. An appropriate dilution of each sample was then assayed for $T_{3}$ content using the method described previously.

\section{Isolation of muscle nuclei and assay of thyroid hormone receptors}

The methods were based on those described previously (Dauncey et al. 1988; Morovat \& Dauncey, 1995). Briefly, muscle samples (approximately $10 \mathrm{~g}$ ) were homogenized in buffer A containing (mmol/l): $\mathrm{K}_{2} \mathrm{HPO}_{4} 0 \cdot 2, \mathrm{KH}_{2} \mathrm{PO}_{4} 0 \cdot 6$, sucrose $250, \mathrm{MgCl}_{2}(\mathrm{pH} \mathrm{6.8)} 1$, with the addition of Triton X-100 (1 ml/1). The homogenates were then filtered through mesh of $35 \mu \mathrm{m}$ pore size. The filtrate was centrifuged at $750 \mathrm{~g}$ for $10 \mathrm{~min}$ and the pellet was washed twice in buffer $A$. The final pellet was layered over buffer B containing (mmol/l): $\mathrm{K}_{2} \mathrm{HPO}_{4}$ 3.5 , sucrose $230, \mathrm{MgCl}_{2}$ (pH 6.8) 1 , and centrifuged at $70000 \mathrm{~g}$ for $40 \mathrm{~min}$. Muscle nuclei were further purified with a centrifugation at $30000 \mathrm{~g}$ for $60 \mathrm{~min}$ in buffer $\mathrm{B}$. The pelleted 
nuclei were washed in buffer $A$ and finally suspended in buffer $C$ containing (mmol/l): tris(hydroxymethyl)aminomethane 20 , sucrose $320, \mathrm{MgCl}_{2} 1$, dithiothreitol (pH 7.4) 5. All procedures were carried out at $4^{\circ}$.

The DNA content of the nuclear extract was determined by fluorimetry. Portions $(200 \mu \mathrm{l})$ of the nuclear suspension containing $20 \mu \mathrm{g}$ DNA were incubated for $30 \mathrm{~min}$ at $37^{\circ}$ with $100 \mu{ }^{125} \mathrm{I}$-labelled $\mathrm{T}_{3}$ and increasing concentrations of unlabelled $\mathrm{T}_{3}$ in buffer $\mathrm{C}$. Tubes used to measure non-specific binding contained a 100 -fold excess of unlabelled $T_{3}$. The nuclei were then centrifuged at $3500 \mathrm{~g}$ for $10 \mathrm{~min}$. The pellet was washed in buffer $\mathrm{A}$ containing Triton X-100 (10 ml/1) and its radioactivity measured on a gamma counter (Autogamma; Canberra Packard, Berks.). Values for specific maximal $\mathrm{T}_{3}$-binding capacity $\left(B_{\text {max }}\right)$ were obtained from Scatchard plots after correction for non-specific binding.

\section{Histochemical analysis and identification of myofibre types}

Serial sections of each muscle were cut on a cryostat (Bright Instruments, Huntingdon, Cambs.) at $-22^{\circ}$ and a thickness of $10 \mu \mathrm{m}$. The plane of the sections was at right angles to the longitudinal axis of the fibres. Muscle sections were air-dried for $30 \mathrm{~min}$ and stained for myosin ATPase (mATPase) (EC 3.6.1.32) after acid (pH 4.35) or alkaline (pH 9.4) pre-incubation using the method of Brooke \& Kaiser (1970). To determine the metabolic characteristics of individual fibres (oxidative $v$. non-oxidative) serial sections were treated to reveal succinate dehydrogenase (SHD) (EC 1.3.99.1) activity using the cytochemical method described previously (Dauncey \& Ingram, 1988). Type I slow-twitch fibres were characterized by their acid-stable-alkali-labile mATPase activity, while type II fast-twitch fibres were characterized by their alkali-stable-acid-labile mATPase activity. SDH staining used in conjunction with mATPase enabled overall classification of fibres into one of the following three categories: type I slow oxidative (SO), type II fast oxidative and glycolytic (FOG), and type II fast glycolytic (FG) fibres. A fourth fibre type (IIC) was also found to occur in skeletal muscles, although the proportion of these fibres was always very small and less than $5 \%$. These IIC fibres were both acid- and alkali-stable and it is generally thought that such fibres probably contain a mixture of fast and slow myosins and are in transition between the fast and slow types.

\section{Measurement of myofibre proportion and size}

The relative proportion of each fibre type was assessed in a standard field area of $109700 \mu \mathrm{m}^{2}$. Fibre typing was carried out on 250-700 fibres counted over at least three fields for each muscle. Thus, proportions of fibre type were based on counts of the number of fibres; these can be converted to fibre volume by correcting for differences in fibre crosssectional area. Mean fibre-type cross-sectional area was determined for a minimum of fifty fibres for each fibre type over three to five fields. All measurements were made using a Seescan A010 research grade image-analysis system (Seescan plc, Cambridge).

\section{${ }^{3} H$-labelled ouabain binding}

The concentration of $\mathrm{Na}^{+}, \mathrm{K}^{+}$-ATPase in muscle samples was determined from the maximal ${ }^{3} \mathrm{H}$-labelled ouabain-binding capacity in the presence of vanadate (Nørgaard et al. 1983). This method enables quantification of the total concentration of $\mathrm{Na}^{+}, \mathrm{K}^{+}$-ATPase in small samples of muscle and the values obtained correspond to the total population of functional $\mathrm{Na}^{+}, \mathrm{K}^{+}$ATPases (Clausen et al. 1987). In brief, frozen muscles samples were cut into segments weighing 2-8 mg, washed and incubated in buffer of the following composition $(\mathrm{mmol} / \mathrm{l})$ : tris(hydroxymethyl)aminomethane $10, \mathrm{MgSO}_{4} 3$, tris-vanadate 1 , and sucrose 250 , $\mathrm{pH} 7 \cdot 2-7 \cdot 4$. The specimens were equilibrated for $2 \mathrm{~h}$ at $37^{\circ}$ in buffer containing ${ }^{3} \mathrm{H}-$ labelled ouabain $(0 \cdot 6 \mu \mathrm{Ci} / \mathrm{ml})$ and unlabelled ouabain at a final concentration of $10^{-6} \mathrm{~mol} / 1$. 
This has been shown previously to allow saturation of all ${ }^{3} \mathrm{H}$-labelled ouabain-binding sites in porcine skeletal muscle (Dauncey \& Burton, 1989). This was followed by four $30 \mathrm{~min}$ washes in ice-cold unlabelled buffer to remove ${ }^{3} \mathrm{H}$-labelled ouabain not bound to the receptors. The specimens were then blotted, weighed on a microbalance and soaked overnight in mini-vials containing $0.5 \mathrm{ml}$ trichloroacetic acid (TCA; $0.3 \mathrm{M}$ ) with $0.1 \mathrm{mmol}$ ouabain carrier $/ 1$ before addition of $2.5 \mathrm{ml}$ optifluor (Pico-fluor; Packard Instrument Co., Groningen, The Netherlands) and liquid-scintillation counting of ${ }^{3} \mathrm{H}$ activity. The amount of ${ }^{3} \mathrm{H}$-labelled ouabain taken up and retained in the specimens was calculated and corrected for non-specific uptake. From each muscle sample, four specimens were taken for measurement, allowing quadruplicate determinations of maximum binding capacity $\left(\mathrm{B}_{\max }\right)$.

\section{$\mathrm{Ca}^{2+}$-dependent ${ }^{32} \mathrm{P}$-labelled ATP incorporation}

The concentration of $\mathrm{Ca}^{2+}$-ATPase was determined by measurement of the $\mathrm{Ca}^{2+}$ dependent steady-state phosphorylation from ${ }^{32} \mathrm{P}$-labelled ATP in crude muscle homogenates (Everts et al. 1989). $\mathrm{Ca}^{2+}$ catalyses the dephosphorylation of ${ }^{32} \mathrm{P}$-labelled ATP leading to incorporation of ${ }^{32} \mathrm{P}$ into the $\mathrm{Ca}^{2+}$-ATPase. Briefly, muscle samples of approximately $40 \mathrm{mg}$ were homogenized at $0^{\circ}$ in buffer of the following composition $(\mathrm{mmol} / \mathrm{l})$ : hepes 5 , sucrose $300, \mathrm{pH} \mathrm{7.4}$, and diluted to a final concentration of $10 \mathrm{mg}$ wet $\mathrm{wt} / \mathrm{ml}$. A portion $(0.2 \mathrm{ml})$ of homogenate was incubated for $30 \mathrm{~s}$ at $0^{\circ}$ with $2.5 \mathrm{ml}$ of a solution of the following composition (mmol/l): imidazole $100, \mathrm{KCl} 100, \mathrm{MgCl}_{2} 5$, ethyleneglycol-bis-( $\beta$-aminoethyl ether) $N, N, N^{\prime}, N^{\prime}$-tetraacetic acid (EGTA) $0 \cdot 5$, in the presence of $0.05 \mathrm{mM}$-ATP, $\gamma-{ }^{32} \mathrm{P}$-labelled ATP $(0.3 \mu \mathrm{Ci} / \mathrm{ml}), \mathrm{pH} 7.4$. The reaction was stopped with $3 \mathrm{ml}$ of a solution of the following composition (mmol/l): $\mathrm{Na}_{4} \mathrm{P}_{2} \mathrm{O}_{7} 10$, $\mathrm{KH}_{2} \mathrm{PO}_{4} 10$, TCA 600 , and the solution was centrifuged at $0^{\circ}$ and $1200 \mathrm{~g}$ for $40 \mathrm{~min}$. The resulting pellet was washed twice with a solution of the following composition $(\mathrm{mmol} / \mathrm{l})$ : $\mathrm{Na}_{4} \mathrm{P}_{2} \mathrm{O}_{7} 10, \mathrm{KH}_{2} \mathrm{PO}_{4} 10$, TCA 60 . The pellet was dissolved in $0.5 \mathrm{ml} \mathrm{NaOH}(1 \mathrm{~mm})$ and ${ }^{32} \mathrm{P}$ activity was measured by liquid-scintillation counting. $\mathrm{Ca}^{2+}$-ATPase concentration was calculated as the difference between the ${ }^{32} \mathrm{P}$ incorporation in the absence and presence of $\mathrm{CaCl}_{2}$, added to obtain a concentration of free $\mathrm{Ca}^{2+}$ of $50 \mu \mathrm{mol} / 1$.

This technique involving crude muscle homogenates determines the concentration of both SR Ca ${ }^{2+}$-ATPase and SL Ca ${ }^{2+}$-ATPase. The contribution made to total $\mathrm{Ca}^{2+}$-ATPase concentration by the SL $\mathrm{Ca}^{2+}$-ATPase is, however, minimal since the contribution of SL to SR membrane area is approximately $1 \%$ and, moreover, SL Ca ${ }^{2+}$-ATPase activity in comparison with the SR $\mathrm{Ca}^{2+}$-ATPase is approximately $3 \%$ (Mickleson et al. 1985). Therefore, most of the total $\mathrm{Ca}^{2+}$-ATPase concentration in skeletal muscle can be attributed to the SR $\mathrm{Ca}^{2+}$ pump.

\section{Plasma cortisol and aldosterone concentrations}

Plasma concentrations of cortisol and aldosterone were measured using commercially available ${ }^{125}$ I-labelled cortisol and ${ }^{125} \mathrm{I}$-labelled aldosterone RIA kits (ICN Biomedicals Inc., Thame, Oxon). These two hormones were measured in addition to plasma TH concentrations because they have both been implicated in regulation of $\mathrm{Na}^{+}, \mathrm{K}^{+}$-pump concentration (Hegyvary, 1977; Dørup, 1996).

\section{Statistical analysis}

The results were analysed using Genstat (Lawes Agricultural Trust, 1987). A paired $t$ test was considered to be the most appropriate statistical test because comparisons were made between pair-fed control and hypothyroid littermate animals of identical parentage. Data are presented as means with their standard errors. Results were considered statistically significant at the $P<0.05,0.01$ or 0.001 levels. 


\section{RESULTS}

\section{Growth rates and feed intakes}

The mean body weight of animals at birth was 1.4 (SE 0.07) $\mathrm{kg}$. Piglets gained approximately $0.4 \mathrm{~kg}$ between birth and $2 \mathrm{~d}$ of age, and then maintained weight for the next $2 \mathrm{~d}$, after they were removed from the sow and the start of bottle-feeding. The pair-feeding regimen ensured that feed intakes were very similar in the two groups of animals. Thus, at the start of treatment on day 4 average feed intakes were 425 and $428 \mathrm{~g}$ for control and hypothyroid groups respectively, and these increased to 739 and $762 \mathrm{~g}$ at $14 \mathrm{~d}$ of age. Growth rates for the two groups were also similar during the $10 \mathrm{~d}$ of treatment. Mean body weights $(\mathrm{kg})$ at 6, 10 and $14 \mathrm{~d}$ were 1.9 (SE 0.09), 2.2 (SE 0.08) and 2.5 (SE 0.08) for the controls, and 2.0 (SE 0.10), 2.3(0.09) and 2.7 (SE 0.09) for the hypothyroid group. The very small difference in growth rate was probably due to a lower resting metabolic rate in the hypothyroid animals.

\section{Thyroid hormone status}

Plasma TH levels. After $10 \mathrm{~d}$ of treatment the mean plasma total $\mathrm{T}_{4}$ concentration was reduced by $32 \%(P<0.01)$ in the hypothyroid group compared with the control group (Table 1). Plasma total $\mathbf{T}_{3}$ concentration was affected similarly, with a mean reduction of $48 \%(P<0.001)$ in the hypothyroid animals compared with the control animals. Analysis of plasma samples taken during treatment showed that at $7 \mathrm{~d}$ of age (i.e. $3 \mathrm{~d}$ of treatment), total $\mathrm{T}_{3}$ concentration (nmol/1) in the hypothyroid animals was 2.4 (SE 0.07) compared with 2.9 (SE 0.09) in the controls $(P<0.05)$, indicating that hypothyroidism was induced rapidly after the start of treatment. Plasma total $T_{4}$ and $T_{3}$ concentrations were very similar between animals within a treatment group. By contrast, the concentrations of free $T_{3}$ were more variable within each group (Fig. 1), ranging from 5.5 to $10.8 \mathrm{pmol} / 1$ for controls and from 1.3 to $7.2 \mathrm{pmol} / 1$ for the hypothyroid group; the average reduction induced by hypothyroidism was $58 \%(P<0.001)$.

Hepatic deiodinase activity. The hepatic 5 -monodeiodinase activities of the control and hypothyroid animals are given in Table 1, which shows a marked difference in the rate of peripheral conversion of $T_{4}$ to $T_{3}$ between the two groups. Thus, after only $10 \mathrm{~d}$ of administration of methimazole and iopanoic acid there was a $74 \%$ reduction in deiodinase activity $(P<0 \cdot 001)$. Deiodinase activity ( $\mathrm{pmol} \mathrm{T}_{3} / \mathrm{min}$ per $\mathrm{mg}$ protein) ranged from 434 to 666 in the controls and from 20 to 172 in the hypothyroid animals. Fig. 1 shows the relationship between hepatic deiodinase activity and plasma free $T_{3}$ concentration. In general, within each group free $T_{3}$ concentration was highest in animals with a high hepatic deiodinase activity, although in some animals with similar deiodinase activity different free $\mathrm{T}_{3}$ concentrations were observed, a finding that may be due to temporal fluctuations in the concentration of free $T_{3}$ (Dauncey \& Morovat, 1993).

Myonuclear $T_{3}$ receptors. A short period of mild hypothyroidism was found to induce a striking up-regulation of nuclear $\mathrm{T}_{3}$ receptors in skeletal muscle (Fig. 2): the maximal $\mathrm{T}_{3}$ binding capacity of $l$. dorsi muscle was increased by $46 \%$ in hypothyroid animals compared with control animals $(P<0 \cdot 001)$. Because of the large amount of muscle needed for determination of nuclear $\mathrm{T}_{3}$-receptor binding, this analysis was performed only on $l$. dorsi and not on soleus and rhomboideus muscles.

\section{Muscle morphology}

Fibre proportions. Table 2 shows that in $l$. dorsi muscle a short period of mild hypothyroidism resulted in a very small, although statistically significant, increase in the relative amount of type I SO fibres, with mean values of 5.4 (SE 0.5$)$ and 7.4 (SE 0.7$) \%$ in 
Table 1. Plasma total thyroxine $\left(T_{4}\right)$ and total and free $3,5,3^{\prime}$-triiodothyronine $\left(T_{3}\right)$ concentrations, and hepatic 5 -monodeiodinase activity $\dagger$

(Mean values with their standard errors for nine pairs of control and hypothyroid animals)

\begin{tabular}{|c|c|c|c|c|c|c|c|c|}
\hline \multirow[b]{3}{*}{ Treatment group } & \multicolumn{6}{|c|}{ Plasma thyroid hormone concentrations } & \multirow{2}{*}{\multicolumn{2}{|c|}{$\begin{array}{c}\text { Hepatic } \\
S^{\prime} \text {-monodeiodinase } \\
\text { activity } \\
\left(\text { pmol } \mathrm{T}_{3} / \text { min per } \mathrm{mg} \text { ) }\right.\end{array}$}} \\
\hline & \multicolumn{2}{|c|}{ Total $\mathrm{T}_{4}(\mathrm{nmol} / \mathrm{l})$} & \multicolumn{2}{|c|}{ Total $\mathrm{T}_{3}(\mathrm{nmol} / \mathrm{l})$} & \multicolumn{2}{|c|}{ Free $T_{3}(\mathrm{pmol} / 1)$} & & \\
\hline & Mean & SE & Mean & $\mathbf{S E}$ & Mean & $\mathrm{SE}$ & Mean & $\mathrm{SE}$ \\
\hline Control & $54 \cdot 8$ & $3 \cdot 4$ & 1.8 & $0 \cdot 1$ & $7 \cdot 7$ & $0 \cdot 7$ & 500 & 27 \\
\hline Hypothyroid & $37 \cdot 0^{* *}$ & 8.6 & $0.9 * * *$ & $0 \cdot 1$ & $3 \cdot 2^{* * *}$ & 0.6 & $132 * * *$ & 48 \\
\hline
\end{tabular}

Mean values were significantly different from those for the controls (paired $t$ test): ${ }^{* *} P<0.01, * * * P<0.001$. $\dagger$ For details of animals and procedures, see pp. 842-843.

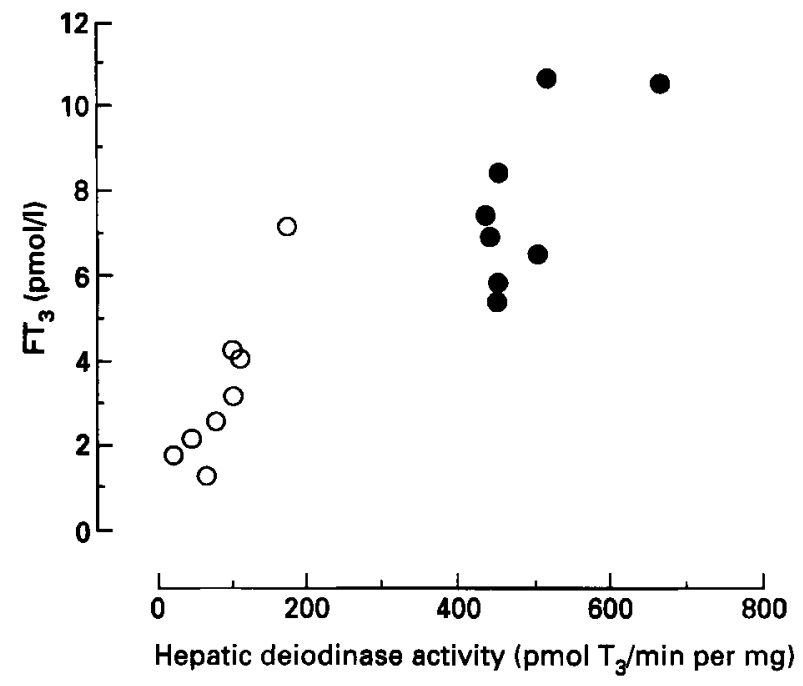

Fig. 1. Relationship between hepatic $5^{\prime}$-monodeiodinase (EC 1.11.1.8) activity and plasma free 3,5,3'triiodothyronine $\left(\mathrm{FT}_{3}\right)$ concentration in control $(\mathrm{O})$, and hypothyroid $(O)$ animals at $14 \mathrm{~d}$ of age. For details of animals and procedures, see pp. 842-843.

control and hypothyroid groups respectively $(P<0.01)$. A more substantial increase in the amount of type I SO fibres was also found in soleus muscle, with mean values of $37 \cdot 1$ (SE 1.0) and 43.4 (SE 1.8$) \%$ in control and hypothyroid animals respectively $(P<0.01)$. However, in rhomboideus muscle no significant difference in fibre-type amounts was observed after the $10 \mathrm{~d}$ period of treatment; mean values for type I SO fibre proportions were $35 \cdot 2$ (SE $2 \cdot 3$ ) and 32.4 (SE 3.6$) \%$ for control and hypothyroid groups respectively $(P=0.65)$.

Fibre cross-sectional areas. Table 3 shows that, in general, no significant difference in fibre-type area was observed between the control and hypothyroid groups. In $l$. dorsi muscle, however, where very little variation between litters occurred in the mean crosssectional area of type II FOG fibres, a statistically significant reduction in area occurred with hypothyroidism, mean values were 297 (SE 20) and 245 (SE 16) $\mu \mathrm{m}^{2}$ in control and hypothyroid animals respectively $(P<0.05)$. Moreover, there was also a tendency for type 

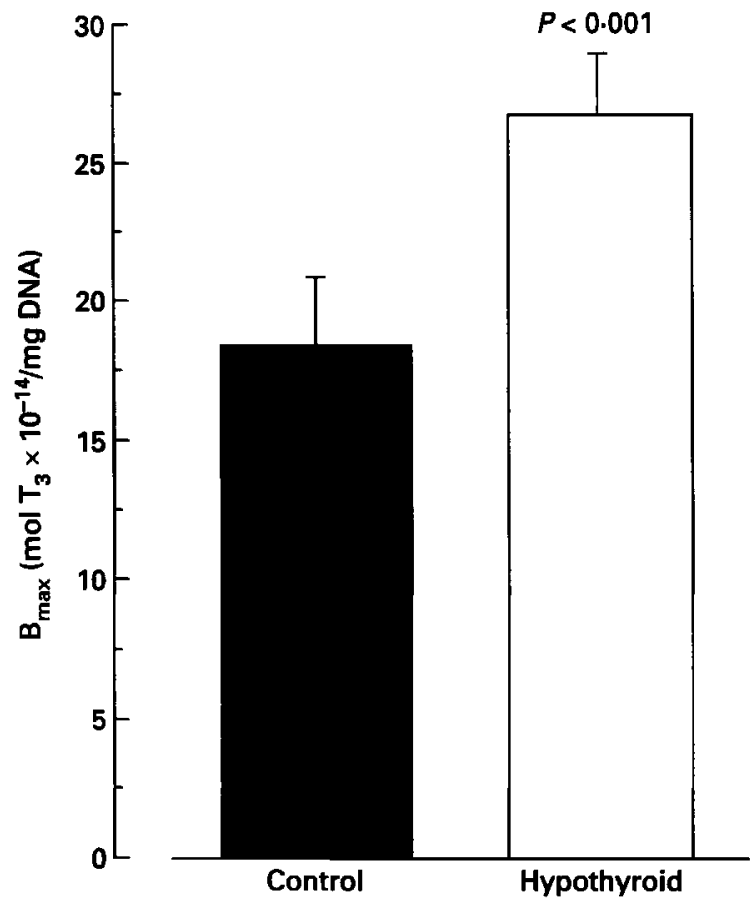

Fig. 2. Maximal $\mathrm{T}_{3}$-receptor-binding capacity $\left(\mathrm{B}_{\max }\right)$ of nuclei from longissimus dorsi muscle of control $(\mathbb{})$ and hypothyroid $(\square)$ animals at $14 \mathrm{~d}$ of age. Values are means with their standard errors from nine pairs of littermate animals. For details of animals and procedures, see pp. 842-844.

Table 2. Relative amounts (\%) of type I slow oxidative (I SO), type II fast oxidative and glycolytic (II FOG), type II fast glycolytic (II FG), and type IIC oxidative and glycolytic fibres in longissimus dorsi (1. dorsi), soleus and rhomboideus musclest

(Mean values with their standard errors for nine pairs of control and hypothyroid animals)

\begin{tabular}{|c|c|c|c|c|c|c|c|c|c|}
\hline \multirow[b]{2}{*}{ Muscle } & \multirow[b]{2}{*}{ Treatment group } & \multicolumn{2}{|c|}{ I SO } & \multicolumn{2}{|c|}{ II FOG } & \multicolumn{2}{|c|}{ II FG } & \multicolumn{2}{|c|}{ IIC } \\
\hline & & Mean & SE & Mean & SE & Mean & SE & Mean & SE \\
\hline \multirow[t]{2}{*}{ L. dorsi } & Control & $5 \cdot 4$ & 0.5 & $48 \cdot 1$ & 0.9 & $45 \cdot 5$ & 1.0 & $1 \cdot 0$ & $0 \cdot 2$ \\
\hline & Hypothyroid & $7 \cdot 4^{* *}$ & 0.7 & $45 \cdot 4$ & $1 \cdot 2$ & $46 \cdot 3$ & $1 \cdot 7$ & 0.9 & $0 \cdot 2$ \\
\hline \multirow[t]{2}{*}{ Soleus } & Control & $37 \cdot 1$ & $1 \cdot 0$ & $58 \cdot 2$ & $1 \cdot 3$ & 0 & 0 & $4 \cdot 7$ & $0 \cdot 6$ \\
\hline & Hypothyroid & $43 \cdot 4^{* *}$ & 1.8 & $52 \cdot 4^{* *}$ & $2 \cdot 2$ & 0 & 0 & $4 \cdot 2$ & 0.7 \\
\hline \multirow[t]{2}{*}{ Rhomboideus } & Control & $35 \cdot 2$ & $2 \cdot 3$ & 59.0 & $2 \cdot 4$ & $3 \cdot 1$ & 0.7 & $2 \cdot 7$ & $1 \cdot 0$ \\
\hline & Hypothyroid & $32 \cdot 4$ & $3 \cdot 6$ & 61.4 & $4 \cdot 0$ & $2 \cdot 8$ & $1 \cdot 1$ & $3 \cdot 4$ & 0.6 \\
\hline
\end{tabular}

Mean values were significantly different from those for the controls (paired $t$ test): ${ }^{* *} P<0 \cdot 01$.

$\dagger$ For details of animals and procedures, see pp. 842-844.

I SO fibres to be smaller in $l$. dorsi but larger in soleus muscles of hypothyroid animals compared with controls.

\section{Skeletal muscle $\mathrm{Na}^{+}, \mathrm{K}^{+}-\mathrm{ATPase}$ concentration}

It was found that a short period of mild hypothyroidism during early postnatal development leads to a reduction in $\mathrm{Na}^{+}, \mathrm{K}^{+}$-ATPase concentration in skeletal muscle, irrespective of muscle type (Fig. 3). Reductions of $15(P<0.05), 16(P<0.001)$ and $16 \%$ 
Table 3. Cross-sectional areas $\left(\mu^{2}\right)$ of type I slow oxidative (I SO), type II fast oxidative and glycolytic (II FOG), type II fast glycolytic (II FG), and type IIC oxidative and glycolytic fibres in longissimus dorsi (1. dorsi), soleus and rhomboideus muscles $\dagger$

(Mean values with their standard errors for nine pairs of control and hypothyroid animals)

\begin{tabular}{|c|c|c|c|c|c|c|c|c|c|}
\hline \multirow[b]{2}{*}{ Muscle } & \multirow[b]{2}{*}{ Treatment group } & \multicolumn{2}{|c|}{ I so } & \multicolumn{2}{|c|}{ II FOG } & \multicolumn{2}{|c|}{ II FG } & \multicolumn{2}{|c|}{ IIC } \\
\hline & & Mean & SE & Mean & $\mathrm{SE}$ & Mean & $\mathbf{S E}$ & Mean & $\mathbf{S E}$ \\
\hline L. dorsi & Control & $\begin{array}{l}426 \\
401\end{array}$ & 20 & 297 & 20 & 291 & 28 & 243 & 21 \\
\hline \multirow[t]{2}{*}{ Soleus } & $\begin{array}{l}\text { Hypothyroid } \\
\text { Control }\end{array}$ & $\begin{array}{l}401 \\
213\end{array}$ & $\begin{array}{l}26 \\
13\end{array}$ & $\begin{array}{l}245^{*} \\
162\end{array}$ & $\begin{array}{r}16 \\
9\end{array}$ & $\frac{256}{-}$ & 20 & $\begin{array}{l}216 \\
125\end{array}$ & $\begin{array}{l}11 \\
10\end{array}$ \\
\hline & Hypothyroid & 253 & 14 & 171 & 13 & - & - & 141 & 10 \\
\hline \multirow[t]{2}{*}{ Rhomboideus } & Control & 393 & 42 & 415 & 33 & 364 & 22 & 263 & 15 \\
\hline & Hypothyroid & 447 & 37 & 375 & 38 & 388 & 54 & 321 & 49 \\
\hline
\end{tabular}

Mean values were significantly different from those for the controls (paired $t$ test): ${ }^{*} \boldsymbol{P}<0-05$.

$\dagger$ For details of animals and procedures, see pp. 842-844.
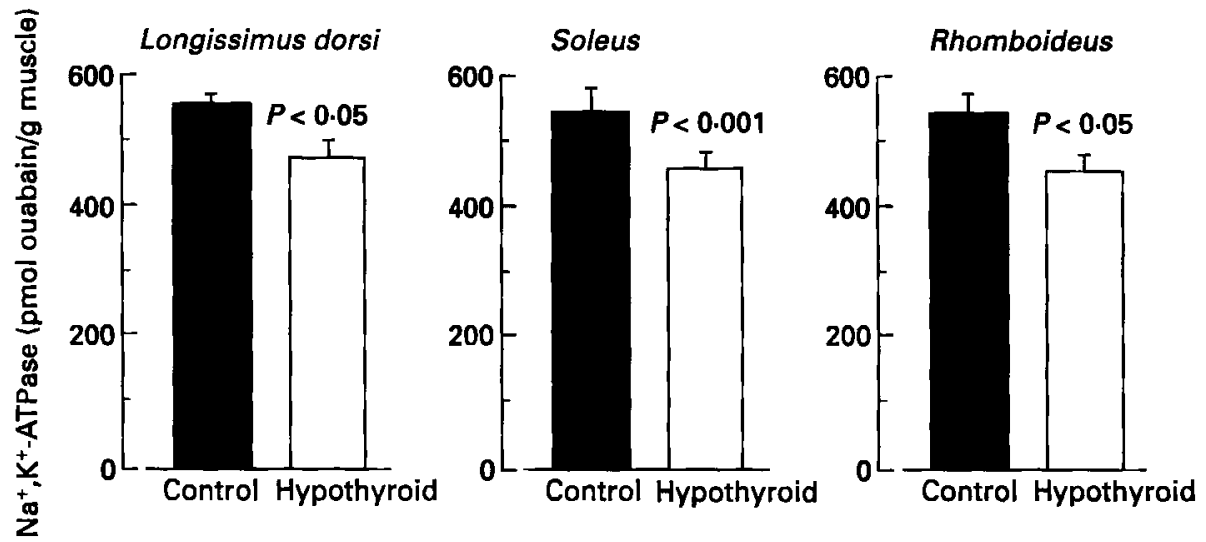

Fig. 3. Total $\mathrm{Na}^{+}, \mathrm{K}^{+}$-ATPase (EC 3.6.1 .37) concentration in skeletal muscles from control ( $\square$ ) and hypothyroid (ㅁ) animals at $14 \mathrm{~d}$ of age; estimated using the vanadate-facilitated ${ }^{3} \mathrm{H}$-labelled ouabain-binding technique. Values are means with their standard errors from nine pairs of littermate animals. For details of animals and procedures, see pp. 842-845.

$(P<0.05)$ occurred in the ${ }^{3} \mathrm{H}$-labelled ouabain-binding site concentration of $l$. dorsi, soleus and rhomboideus muscles respectively, of hypothyroid compared with control animals.

In treatment groups with very large differences in muscle fibre size it can be more meaningful to present results for $\mathrm{Na}^{+}, \mathrm{K}^{+}$-ATPase concentration in relation to SL area rather than to muscle weight (Harrison et al. 1994b). However, differences in fibre size in the present study were very small (Table 3 ) and, therefore, results have been presented only in relation to muscle weight. It can, nevertheless, be estimated that the difference in $\mathrm{Na}^{+}, \mathrm{K}^{+}$-ATPase concentration between control and hypothyroid animals would have been even greater if results had been expressed in relation to SL area.

\section{Skeletal muscle $\mathrm{Ca}^{2+}-$ ATPase concentration}

A short period of mild hypothyroidism was found to reduce the concentration of $\mathrm{Ca}^{2+}$. ATPase in skeletal muscle (Fig. 4). However, in the fast-twitch muscle $l$. dorsi the $11 \%$ reduction was not statistically significant $(P=0.20)$ because of the wide variation between 

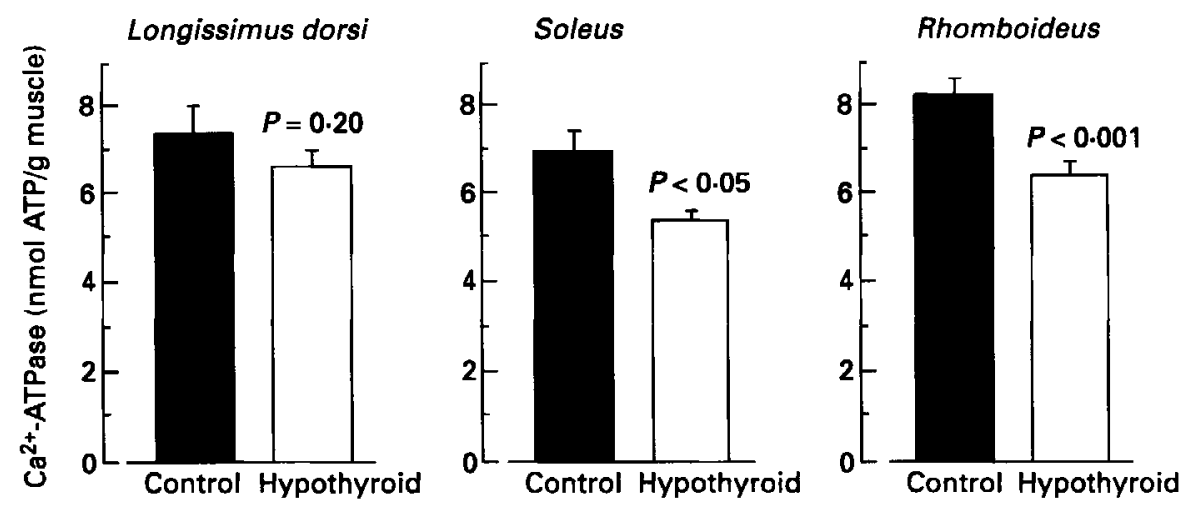

Fig. 4. Total $\mathrm{Ca}^{2+}$-ATPase (EC 3.6.1.38) concentration in skeletal muscles from control ( $\square$ ) and hypothyroid (口) animals at $14 \mathrm{~d}$ of age; estimated from $\mathrm{Ca}^{2+}$-dependent steady-state phosphorylation from ${ }^{32}$ P-labelled ATP. Values are means with their standard errors from nine pairs of littermate animals. For details of animals and procedures, see pp. 842-845.

litters. By contrast, in the slow-twitch muscles soleus and rhomboideus a more consistent decrease in $\mathrm{Ca}^{2+}$-ATPase concentration occurred, with a period of mild hypothyroidism resulting in mean reductions of $23(P<0.05)$ and $22 \%(P<0.001)$ respectively.

\section{Plasma cortisol and aldosterone concentrations}

Plasma cortisol concentration was $18 \%$ lower in hypothyroid compared with control animals; mean values were 42.8 (SE 11.7 ) and 52.4 (SE 8.1) nmol/l respectively. However, there was wide variation between litters and no significant difference between the two treatment groups $(P=0-50)$. No difference in aldosterone levels were observed between the control and hypothyroid groups; mean values were 47.8 (SE 6.1) and $47 \cdot 7$ (SE 9.2) pmol/l respectively.

\section{DISCUSSION}

The present results have shown that in early postnatal life a short period of mild hypothyroidism, comparable with that occurring during undernutrition, induced downregulation of two cation pumps essential for normal muscle function, the $\mathrm{SL} \mathrm{Na}^{+}, \mathrm{K}^{+}$ATPase and the SR $\mathrm{Ca}^{2+}$-ATPase. This response was rapid, occurring within $10 \mathrm{~d}$ of treatment, and was not associated with other effects of chronic severe hypothyroidism such as reduced feed intake or marked changes in fibre type proportions. Up-regulation of nuclear $T_{3}$ receptors with pharmacologically-induced hypothyroidism in animals receiving an adequate energy intake may have buffered the effects of low plasma TH levels, suggesting a homeostatic mechanism at the level of the myocyte which increases the sensitivity to low levels of TH. Comparisons between three functionally different muscles suggest that in early postnatal development $\mathrm{Na}^{+}, \mathrm{K}^{+}$-ATPase concentration is affected to the same extent in all muscles irrespective of fibre type, whereas $\mathrm{Ca}^{2+}$-ATPase concentration may be regulated by TH in a muscle-specific fashion. The significance of these findings is considered in the following sections.

\section{Down-regulation of $\mathrm{Na}^{+}, \mathrm{K}^{+}-$ATPase by hypothyroidism}

The present study has shown that a pharmacologically-induced $50 \%$ reduction in plasma TH concentrations results in a $15 \%$ down-regulation in $\mathrm{Na}^{+}, \mathrm{K}^{+}$-ATPase concentration in both slow- and fast-twitch muscles, in 2-week-old piglets compared with their pair-fed control littermates (Fig. 3). These results extend previous findings in which down- 
regulation of this enzyme has been shown to occur after long periods of chronic severe hypothyroidism (Kjeldsen et al. 1986a), by showing that down-regulation of pump concentration can be induced by a short period of mild hypothyroidism, and that the effects of hypothyroidism on pump concentration are not related to a reduction in feed intake. Moreover, even within the control group there was a direct correlation between plasma $T_{3}$ levels and $\mathrm{Na}^{+}, \mathrm{K}^{+}$-ATPase concentration of the slow-twitch muscles soleus $(r 0 \cdot 85, P<$ $0.01)$ and rhomboideus $(r 0.76, P<0.05)$, and this correlation was reinforced when the hypothyroid piglets were taken into account. In the fast-twitch $l$. dorsi there was, however, no such correlation within the control group $(r 0.46, P<0 \cdot 20)$.

The probability is that this down-regulation in $\mathrm{Na}^{+}, \mathrm{K}^{+}$-ATPase was directly due to the reduction in TH levels rather than to indirect changes in other endocrine factors. Thus, aldosterone, which modulates the concentration of $\mathrm{Na}^{+}, \mathrm{K}^{+}$-ATPase in cardiac SL (Hegyvary, 1977), was not significantly affected by the short period of hypothyroidism. Similarly, cortisol, which can up-regulate $\mathrm{Na}^{+}, \mathrm{K}^{+}$-ATPase concentration in muscle (Dørup, 1996), was not significantly altered in hypothyroid piglets compared with control piglets. The tendency for plasma cortisol to be lower in the hypothyroid group may, however, have made a small contribution to the lower $\mathrm{Na}^{+}, \mathrm{K}^{+}$-ATPase values in these animals. It is unlikely that the changes in concentration of $\mathrm{Na}^{+}, \mathrm{K}^{+}$-ATPase induced by hypothyroidism resulted from changes in fibre type because these changes were small (Table 2) and not consistent with any previously suggested relationship between $\mathrm{Na}^{+}, \mathrm{K}^{+}$-ATPase concentration and fibre type (Dauncey et al. 1994; Harrison et al. 1994b).

Despite the clear relationship between thyroid status and $\mathrm{Na}^{+}, \mathrm{K}^{+}$-ATPase concentration reported in the present and previous studies (Clausen et al. 1991), it is relevant to note that these two variables are not invariably related. Thus, reduced $\mathrm{TH}$ levels in young pigs living in a warm environment and receiving $50 \%$ of the energy intake of controls for 4 weeks did not alter $\mathrm{Na}^{+}, \mathrm{K}^{+}$-pump concentrations (Dauncey \& Burton, 1989; Harrison et al. 1994b). By contrast, in 12-week-old rats a similar level of undernutrition for only 2 weeks was related to a reduction in both plasma $\mathrm{T}_{3}$ and $\mathrm{Na}^{+}, \mathrm{K}^{+}$-ATPase concentration (Kjeldsen et al. $1986 b$ ). In keeping with these results in the rat is the finding that $T_{3}$ administration to fasting rats restores normal $\mathrm{Na}^{+}, \mathrm{K}^{+}$-ATPase concentration (Matsumura et al. 1992) suggesting that the fasting-induced decrease in pump concentration was due at least in part to the decrease in plasma $T_{3}$ levels. These contrasting results are not easy to interpret but may be related to differences in age, species or relative severity of the undernutrition. A potentially important factor is that the young pig has a high ad libitum feed intake and, therefore, even those on a $50 \%$ intake continue to grow, whereas the $50 \%$ restricted rat shows a severe reduction in growth rate.

An additional factor which may help to explain differences between studies is the number of nuclear $\mathbf{T}_{3}$ receptors, which is likely to affect the tissue response to the hormone. The $46 \%$ up-regulation of $\mathrm{T}_{3}$ receptors in $l$. dorsi muscle in the present study has been reported previously after removal of the thyroid gland or pharmacologically-induced hypothyroidism (Duchamp et al. 1994; Morovat \& Dauncey, 1995). By contrast, however, a nutritionally-induced reduction in plasma $\mathrm{TH}$ levels results in down-regulation of $\mathrm{T}_{3}$ receptors in $l$. dorsi muscle of young pigs (Dauncey et al. 1988). Reasons for this difference are not known but may be related to differences in energy balance (Morovat \& Dauncey, 1995). Future investigations, therefore, need to clarify the complex interactions between energy balance and TH status in the acute and long-term regulation of $\mathrm{Na}^{+}, \mathrm{K}^{+}-\mathrm{ATPase}$ concentration.

\section{Down-regulation of $\mathrm{Ca}^{2+}-A T P$ ase by hypothyroidism}

The present study has shown that mild hypothyroidism in pair-fed piglets during the first 2 weeks of postnatal life results in a $22-23 \%$ reduction in $\mathrm{Ca}^{2+}$-ATPase concentration in 
skeletal muscle (Fig. 4). These results extend the findings of earlier studies in which the $\mathrm{Ca}^{2+}$-accumulating ability of SR from rat muscles was decreased after thyroidectomy (Nwoye et al. 1982) as a result of down-regulation of $\mathrm{Ca}^{2+}$-ATPase concentration (Simonides \& van Hardeveld, 1989), by showing that a short period of mild hypothyroidism also reduces $\mathrm{Ca}^{2+}$-ATPase concentration in skeletal muscle. It has been observed also that the mRNA levels of SR $\mathrm{Ca}^{2+}$-ATPase are affected; they decrease in hypothyroidism and increase in hyperthyroidism (Rohrer \& Dillmann, 1988; Arai et al. 1991), confirming that in chronic hypothyroidism, at least, regulation of $\mathrm{Ca}^{2+}$ uptake is accomplished primarily by decreasing the number of functional pumps. The present results further increase understanding of the hormonal regulation of $\mathrm{Ca}^{2+}$-ATPase by showing that downregulation of pump numbers by hypothyroidism is not related to alterations in feed intake, and that regulation of $\mathrm{Ca}^{2+}$-ATPase concentration may be muscle-specific because it was significantly altered only in soleus and rhomboideus muscles.

Thus, not only do TH exert different effects on myosin genes in different types of muscles (Izumo et al. 1986; d'Albis \& Butler-Browne, 1993; Dauncey \& Gilmour, 1996) but they may also regulate the expression of $\mathrm{Ca}^{2+}$-ATPase in a muscle-specific fashion. Indeed, it has been reported previously that TH can have dual and opposite effects on the expression of different genes in skeletal muscle fibres (Izumo et al. 1986; Muller et al. 1994). The present results suggest that the muscle-specific regulation of $\mathrm{Ca}^{2+}$-ATPase cannot be related simply to the proportions of fibre type in muscles because there were no marked differences in $\mathrm{Ca}^{2+}$-ATPase concentration in the three muscles studied from control piglets despite differences in their proportions of fibre type (Fig. 4 and Table 2). Thus, muscle-specific differences in nuclear $T_{3}$ receptors, local $\mathrm{TH}$ metabolism, and neuronal and hormonal signals altered by TH may also play a role. Indeed, different isoforms of nuclear $T_{3}$ receptors have been described (Lazar, 1993) and it has been shown that their expression as well as their response to changes in thyroid status may differ according to muscle phenotype (Hoffman et al. 1994).

\section{Changes in muscle function induced by hypothyroidism}

Despite the short period of administration of methimazole and iopanoic acid, small, but significant, increases in type I SO fibre proportions occurred in $l$. dorsi and soleus muscles (Table 2). This suggests that the effects of hypothyroidism on the expression of myosin ATPase isoforms are rapid and can occur within $10 \mathrm{~d}$, especially in young animals. In support of this finding, rapid effects of $T_{3}$ on proportions of fibre type have also been reported in 20-week-old hypothyroid rats $14 \mathrm{~d}$ after administration of $\mathrm{T}_{3}$ (Montgomery, 1992). By contrast with the present findings for $l$. dorsi and soleus muscles, changes in fibre type were not observed in rhomboideus muscle. Although it is difficult to interpret this finding, it may be associated with muscle-specific effects of TH on the myosin gene family (Izumo et al. 1986). Moreover, the specific role of rhomboideus muscle in thermoregulation (Harrison et al. 1996) may also contribute to such a difference.

Although there was only a slight change in the proportions of fibre type in $l$. dorsi, the observation that it changes over a relatively short period suggests that more prolonged hypothyroidism will be of importance for energy conservation, especially as this muscle is one of the largest in the body. Moreover, a consequence of an increase in proportion of type I SO fibres combined with down-regulation of $\mathrm{Na}^{+}, \mathrm{K}^{+}$- and $\mathrm{Ca}^{2+}-\mathrm{ATPases}$ is probably slowness of movement, muscle weakness and improved energetic efficiency due to a reduction in the quantity of ATP hydrolysed to maintain $\mathrm{Na}^{+}, \mathrm{K}^{+}$homeostasis and sequester $\mathrm{Ca}^{2+}$. Alterations in contractile properties of the muscles may even have preceded changes in their fibre types because changes in isometric force and velocity 
properties of muscles have been detected as early as $2 \mathrm{~d}$ after $\mathrm{T}_{3}$ administration to hypothyroid rats (Montgomery, 1992). Indeed, the rapidity with which these changes in contractile properties occurred may have been related to rapid changes in the number of cation pumps because these can occur within a $24 \mathrm{~h}$ period (Dauncey et al. 1991). Moreover, the responsiveness of muscle to TH may be particularly marked during early development, when there are marked changes in cation-pump concentrations (Harrison et al. 1994a; Dauncey et al. 1994; Dauncey \& Harrison, 1996). Not only is hypothyroidism associated with a reduction in $\mathrm{Ca}^{2+}$-ATPase gene expression but there is also overexpression of its inhibitor, phospholamban (Kiss et al. 1994), and these changes would contribute to a depression of both $\mathrm{Ca}^{2+}$ uptake and muscle relaxation rate.

Whether the present effects on myofibre cation pumps would impair subsequent development after a euthyroid state had been achieved remains to be investigated. However, studies on intact rat skeletal muscle (Kjeldsen et al. 1986a) and cultured rat skeletal myotubes (Brodie \& Sampson, 1989) indicated that although TH increased the concentrations of $\mathrm{Na}^{+}-\mathrm{K}^{+}$pumps and $\mathrm{Na}^{+}$channels, the newly synthesized pumps had a reduced affinity for their respective ligands. Moreover, preliminary data from small-forgestational age piglets, which have been undernourished before birth, suggest that not only are $\mathrm{Na}^{+}, \mathrm{K}^{+}$- and $\mathrm{Ca}^{2+}$-ATPase concentrations lower at birth than those of control littermates but they remain lower at $14 \mathrm{~d}$ postnatally (Dauncey \& Harrison, 1996).

\section{Conclusions}

A short period of mild hypothyroidism during early postnatal development was found to induce down-regulation of two cation pumps essential for normal muscle function, the SL $\mathrm{Na}^{+}, \mathrm{K}^{+}$-ATPase and the SR $\mathrm{Ca}^{2+}$-ATPase. This effect on cation-pump concentrations was rapid and could not be explained by any indirect effects of the hypothyroid state such as reduced feed intake, changes in myofibre type or alterations in the circulating levels of other hormones. The possibility that proportions of myofibre type and $\mathrm{Ca}^{2+}$-ATPase concentration may be regulated by $\mathrm{TH}$ in a muscle-specific fashion via the differential expression of the various isoforms of nuclear $T_{3}$ receptors should be the focus of future investigation. The consequence of these changes in muscle development at the cellular level would be slowness of movement, muscle weakness and improved energetic efficiency. Results hold important implications for muscle function of neonates with low thyroid status resulting from a reduction in energy intake due to illness or restricted food supply.

The authors thank D. Brown, The Babraham Institute's senior statistician, for statistical advice; K. A. Burton for help with the animal studies; and T. Lindahl Andersen, B. Mortensen and E. de Neergaard for measurement of $\mathrm{Na}^{+}, \mathrm{K}^{+}$- and $\mathrm{Ca}^{2+}$-ATPases. A.P.H. was supported by a BBSRC Research Studentship, The Babraham Institute is supported by the BBSRC and the study was also supported in part by Danish Medical Research Council Grant 12-9262 and the Biomembrane Research Center of the University of Aarhus.

\section{REFERENCES}

Acheson, K. J. \& Burger, A. G. (1980). A study of the relationship between thermogenesis and thyroid hormones. Journal of Clinical Endocrinology and Metabolism 51, 84-89.

Arai, M., Otsu, K., MacLennan, D. H., Alpert, N. R. \& Periasamy, M. (1991). Effect of thyroid hormone on the expression of mRNA encoding sarcoplasmic reticulum proteins. Circulation Research 69, $266-276$.

Brodie, C. \& Sampson, S. R. (1989). Characterization of thyroid hormone effects on $\mathrm{Na}$ channel synthesis in cultured skeletal myotubes: role of $\mathrm{Ca}^{2+}$. Endocrinology 125, 842-849.

Brooke, M. H. \& Kaiser, K. K. (1970). Three 'myosin adenosine triphosphatase' systems: The nature of their pH lability and sulfhydryl dependence. Journal of Histochemistry and Cytochemistry 18, 670-672. 
Clausen, T., Everts, M. E. \& Kjeldsen, K. (1987). Quantification of the maximum capacity for active sodium potassium transport in rat skeletal muscle. Journal of Physiology 388, 163-181.

Clausen, R., van Hardeveld, C. \& Everts, M. E. (1991). Significance of cation transport in control of energy metabolism and thermogenesis. Physiological Reviews 3, 733-774.

d'Albis, A. \& Butler-Browne, G. (1993). The hormonal control of myosin isoform expression in skeletal muscle of mammals: a review. Basic and Applied Myology 3, 7-16.

Dauncey, M. J. (1990). Thyroid hormones and thermogenesis. Proceedings of the Nutrition Society 49, $203-215$.

Dauncey, M. J., Brown, D., Hayashi, M. \& Ingram, D. L. (1988). Thyroid hormone nuclear receptors in skeletal muscle as influenced by environmental temperature and energy intake. Quarterly Journal of Experimental Physiology 73, $183-191$.

Dauncey, M. J. \& Burton, K. A. (1989). ${ }^{3} \mathrm{H}$-Ouabain binding sites in porcine skeletal muscle as influenced by environmental temperature and energy intake. Pfiügers Archiv: European Journal of Physiology 414, $317-323$.

Dauncey, M. J., Burton, K. A. \& Morovat, A. (1991). Variations in $\left[{ }^{3} \mathrm{H}\right]$ ouabain binding of porcine skeletal muscle associated with feeding. Experimental Physiology 76, 967-970.

Dauncey, M. J., Clausen, T. \& Harrison, A. P. (1994). Developmental regulation of $\mathrm{Na}^{+}, \mathrm{K}^{+}-$and $\mathrm{Ca}^{2+}-\mathrm{ATPases}$ in muscle. In Modern Trends in BioThermoKinetics, vol. 3, pp. 163-168 [E. Gnaiger, F. N. Gellerich and M. Wyss, editors]. Innsbruck: Innsbruck University Press.

Dauncey, M. J. \& Gilmour, R. S. (1996). Regulatory factors in the control of muscle development. Proceedings of the Nutrition Society 55, 543-559.

Dauncey, M. J. \& Harrison, A. P. (1996). Developmental regulation of cation pumps in skeletal and cardiac muscle. Acta Physiologica Scandinavica 156, 313-323.

Dauncey, M. J. \& Ingram, D. L. (1988). Influence of environmental temperature and energy intake on skeletal musle respiratory enzymes and morphology. European Journal of Applied Physiology 58, 239-244.

Dauncey, M. J. \& Morovat, A. (1993). Investigation of mechanisms mediating the increase in plasma concentrations of thyroid hormones after a meal in young growing pigs. Journal of Endocrinology 139, 131-141.

Dørup, I. (1996). Effects of $\mathrm{K}^{+}, \mathrm{Mg}^{2+}$ deficiency and adrenal steroids on $\mathrm{Na}^{+}-\mathrm{K}^{+}$pump concentration in skeletal muscle. Acta Physiologica Scandinavica 156, 305-311.

Duchamp, C., Burton, K. A., Herpin, P. \& Dauncey, M. J. (1994). Perinatal ontogeny of porcine nuclear 3,5,3'triiodothyronine receptors and its modification by thyroid status. American Journal of Physiology $267,687-693$.

Everts, M. E., Andersen, J. P., Clausen, T. \& Hansen, O. (1989). Quantitative determination of Ca ${ }^{2+}$-dependent $\mathrm{Mg}^{2+}$-ATPase from sarcoplasmic reticulum in muscle biopsies. Biochemical Journal 260, 443-448.

Gold, H. K., Spann, J. F. \& Braunwald, E. (1970). Effect of alterations in the thyroid state on the intrinsic contractile properties of isolated rat skeletal muscle. Journal of Clinical Investigation 49, 849-854.

Harrison, A. P., Clausen, T. \& Dauncey, M. J. (1994a). Cation pumps in skeletal muscle undergo dramatic upregulation in the perinatal period. Proceedings of the Nutrition Society 53, 246A.

Harrison, A. P., Clausen, T., Duchamp, C. \& Dauncey, M. J. (1994b). Roles of skeletal muscle morphology and activity in determining $\mathrm{Na}^{+}, \mathrm{K}^{+}$-ATPase concentration in young pigs. American Journal of Physiology 35, R102-R111.

Harrison, A. P., Clausen, T., Tivey, D. R. \& Dauncey, M. J. (1994 c). Regulation of Na $\mathrm{Na}^{+}, \mathrm{K}^{+}$-ATPase concentration in skeletal muscle of neonatal pigs: role of thyroid hormones. Journal of Endocrinology 140, P65.

Harrison, A. P., Rowlerson, A. M. \& Dauncey, M. J. (1996). Selective regulation of myofiber differentiation by energy status during postnatal development. American Journal of Physiology 270, R667-R674.

Harrison, A. P., Tivey, D. R., Duchamp, C. \& Dauncey, M. J. (1993). Neonatal hypothyroidism and its influence on contractile and metabolic properties of skeletal muscle. Journal of Endocrinology 139, P49.

Hegyvary, C. (1977). Effect of aldosterone and methylprednisolone on cardiac NaK-ATPase. Experientia 33, 1280-1281.

Hoffman, R. K., Lazar, M. A., Rubinstein, N. A. \& Kelly, A. M. (1994). Differential expression of $\alpha 1, \alpha 2$ and $\beta 1$ thyroid hormone receptor genes in developing rat skeletal muscle. Journal of Cell Biochemistry $18 \mathrm{D}, 517$.

Izumo, S., Nadal-Ginard, B. \& Mahdavi, V. (1986). All members of the MHC multigene family respond to thyroid hormone in a highly tissue-specific manner. Science 231, 597-600.

Kiss, E., Jakab, G., Kranias, E. G. \& Edes, I. (1994). Thyroid hormone-induced alterations in phospholamban protein expression. Regulatory effects on sarcoplasmic reticulum $\mathrm{Ca}^{2+}$ transport and myocardial relaxation. Circulation Research 75, 245-251.

Kjeldsen, K., Everts, M. E. \& Clausen, T. (1986a). The effects of thyroid hormones on ${ }^{3} \mathrm{H}$-ouabain binding site concentration, $\mathrm{Na}, \mathrm{K}$-contents and ${ }^{86} \mathrm{Rb}$-efflux in rat skeletal muscle. Pflügers Archiv: European Journal of Physiology 46, 529-535.

Kjeldsen, K., Everts, M. E. \& Clausen, T. (1986b). Effects of semi-starvation and potassium deficiency on the concentration of $\left[{ }^{3} \mathrm{H}\right]$ ouabain-binding sites and sodium and potassium contents in rat skeletal muscle. British Journal of Nutrition 56, 519-532.

Kühn, E. R., Verheyen, G., Chiasson, R. B., Huts, C., Huybrechts, L., Van den Steen, P. \& Decuypere, E. (1987). Growth hormone stimulates the peripheral conversion of thyroxine into triiodothyronine by increasing the liver 5 -monodeiodinase activity in the fasted and normal fed chicken. Hormone and Metabolic Research 19, $304-308$.

Lawes Agricultural Trust (1987). Genstat 5. Rothamsted, Herts.: Lawes Agricultural Trust.

Lazar, M. A. (1993). Thyroid hormone receptors: Multiple forms, multiple possibilities. Endocrine Reviews 14, 184-193. 
McAllister, R. M., Ogilvie, R. W. \& Terjung, R. L. (1991). Functional and metabolic consequences of skeletal muscle remodeling in hypothyroidism. American Journal of Physiology 260, E272-E279.

Matsumura, M., Kuzuya, N., Kawakami, Y. \& Yamashita, K. (1992). Effects of fasting, refeeding, and fasting with $T_{3}$ administration on Na-K,ATPase in rat skeletal muscle. Metabolism 41, 995-999.

Mickleson, J. R., Beaudry, T. M. \& Louis, C. F. (1985). Regulation of skeletal muscle sarcoplasmic ATPdependent calcium transport by calmodulin and cAMP-dependent protein kinase. Archives of Biochemistry and Biophysics 242, 127-136.

Montgomery, A. (1992). The time course of thyroid-hormone-induced changes in the isotonic and isometric properties of rat soleus muscle. Pflügers Archiv: European Journal of Physiology 421, 350-356.

Morovat, A. \& Dauncey, M. J. (1995). Regulation of porcine skeletal muscle nuclear 3,5,3'-triiodothyronine receptor binding capacity by thyroid hormones: modification by energy balance. Journal of Endocrinology 144, 233-242.

Mount, L. E. (1979). Adaptation to Thermal Environment. London: Edward Arnold.

Muller, A., van der Linden, G. C., Zuidwijk, M. J., Simonides, W. S., van der Laarse, W. J. \& van Hardeveld, C. (1994). Differential effects of thyroid hormone on the expression of sarcoplasmic reticulum $\mathrm{Ca}^{2+}$-ATPase isoforms in rat skeletal muscle fibers. Biochemical and Biophysical Research Communications 203, 1035-1042.

Nørgaard, A., Kjeldsen, K., Hansen, O. \& Clausen, T. (1983). A simple and rapid method for the determination of the number of ${ }^{3} \mathrm{H}$-ouabain binding sites in biopsies of skeletal muscle. Biochemical and Biophysical Research Communications 111, 319-325.

Nwoye, L., Mommaerts, W. F., Simpson, D. R., Seraydarian, K. \& Marusich, M. (1982). Evidence for a direct action of thyroid hormone in specifying muscle properties. American Journal of Physiology 242, R401-R408.

Rohrer, D. \& Dillmann, W. H. (1988). Thyroid hormone markedly increases the mRNA coding for sarcoplasmic reticulum $\mathrm{Ca}^{2+}$-ATPase in the rat heart. Journal of Biological Chemistry 263, 6941-6944.

Simonides, W. S. \& van Hardeveld, C. (1989). The postnatal development of sarcoplasmic reticulum $\mathrm{Ca}^{2+}$ transport activity in skeletal muscle of the rat is critically dependent on thyroid hormone. Endocrinology 124, $1145-1153$.

Ślebodziński, A. B., Ingram, D. L. \& Dauncey, M. J. (1985). Conversion of thyroxine into 3,5,3'-triiodothyronine and 3,3', $5^{\prime}$-triiodothyronine in the young pig. Comparative Biochemistry and Physiology 80A, 559-563. 